\title{
AGRICULTURAL FRANCHISING AND CONTRIBUTION TO ACHIEVING OBJECTIVES OF THE EU COMMON AGRICULTURAL POLICY ${ }^{1}$
}

\author{
Milica Stanković
}

\section{Summary}

The Common Agricultural Policy is the oldest, the most complex, the most expensive EU policy and it represents one of the most important drivers of European integration. Agrarian franchising is one of the innovations in the field of franchising, which implementation is still in its infancy and it is necessary to strive for the popularization of this business model. The aim of the paper is to emphasize the importance of agricultural franchising concept development and contribution of implementation of this concept to the achievement of the Common Agricultural Policy objectives and improvement of the agrarian sector as a whole. Special attention is paid on agricultural franchising as a hybrid form of disinvestment in conditions of economic crisis. Based on analysis of advantages and disadvantages of agricultural franchising, we conclude that it has the potential for solving a large number of problems that occur in the agrarian sector, with a particular focus on the importance of agricultural franchising to the achievement of the CAP objectives.

Key words: Common Agricultural Policy, EU, agricultural franchising, disinvestment, CAP objectives.

JEL: $Q 13, Q 18,031,033$

\section{Introduction}

The Common Agricultural Policy of the European Union (CAP) is formed since the creation of the European Economic Community. Therefore, it can be said that the Common Agricultural Policy is the oldest, but also the most complex and the most expensive EU policy. The original objective of the CAP is related to the provision of self-sufficiency in food, due to food shortages after World War II. Since its inception, CAP has gone through a

1 The paper does not contain particular research since agricultural franchising is an innovative business model, and its intensive implementation is expected in the future. In order to highlight the need for the implementation of agricultural franchising, the paper focuses on the contributions and benefits that this business model provides for agricultural policy and agricultural sector as a whole.

2 Milica Stanković, M.Sc., Teaching Assistant, Higher School of Professional Business, Vladimir Perić Street no. 4, 21000 Novi Sad, Serbia, Phone: +381 2148540 00, E-mail: milica.stankovic.vps@gmail.com

EP 2014 (61) 4 (1021-1035) 
number of reforms. Through the effective implementation of the measures of the Common Agricultural Policy, EU member states have managed to become net exporters of agricultural products. During the long history of the development of the CAP the tendency was to achieve predefined objectives related to the improving the living standards of rural population, increasing agricultural productivity, stabilizing agricultural markets, regularity in food supply and ensuring reasonable prices for consumers.

Franchising as a business model is in the focus of a growing number of scientific and research studies, but it is necessary to pay more attention to agricultural franchising as an innovative business model. Franchising can be defined as a commercial relationship in which one party allows the other side to clone verified business model in exchange for the initial costs and ongoing fees. In line with current trends in the global environment, it should be emphasized the need for implementation of innovation in franchise concepts. Although innovative franchises are not usual business models, the application of this concept in the agricultural sector will bring much more benefits than disadvantages, so it is expected more intensive encouraging and popularization of agriculture franchising in the future. It is assumed that agricultural franchising contributes to achieving objectives of the Common Agricultural Policy of the European Union. Also, one of the assumptions in the paper is that agricultural franchising has many advantages which enable solving common economic problems that occur in the agricultural sector. Based on the analysis, author will try to confirm the initial hypothesis and obtain relevant conclusions.

The aim of this paper is to emphasize the importance of the development of the agricultural franchising and contribution of this concept implementation for the agricultural sector as a whole, with a particular focus on the contribution to the achievement of the EU Common Agricultural Policy objectives. The first part of the paper explains the concept of franchising as one of the most effective ways for a brand to reach global coverage, with special emphasis on agricultural franchising as one of the innovations in the field of franchising and prerequisites that must be met in order to implement this concept successfully. In the second part, we point out economic problems that commonly occur in the agricultural sector and potential advantages and disadvantages of agricultural franchising concept. The third part refers to agricultural franchising as a hybrid form of disinvestment in conditions of economic crisis. The fourth part of the paper focuses on objectives of the Common Agricultural Policy and the contribution of agriculture franchising for achieving these goals. Based on comprehensive analysis, we provide relevant conclusions and implications for future research.

\section{Methodology and data-sources}

This paper summarizes the data obtained from the analysis of the relevant available sources of literature on agricultural franchising as an innovative business concept and its importance for achieving the objectives of the Common Agricultural Policy. Data were collected from scientific research papers, conference papers, books and online brochures. Sources of recent date are mainly used, in order to give a comprehensive view of contemporary attitudes about the topic and to provide a basis for future research in the field of agricultural franchising. In addition to the analysis and synthesis of all the data obtained from available literature 
sources, author provides her observations on the contribution of the agricultural franchising for achieving the objectives of the CAP.

\section{The concept of franchising and its implementation in the agricultural sector}

An increasing number of researchers put franchising as a business model in the focus of their studies. Number of franchises grows every day, bearing in mind that franchising offers better financial results and greater chance of survival than alternative organizational forms (Nijmeijer et al., 2013). By entering the world of franchising, we get complete business model that should be applied, and the risk is much lower than with starting an independent business. It can be said that the franchising is challenging concept, because it involves cooperation between two very different types of entrepreneurs (Barthelemy, 2008). Franchising implies business interaction between two reciprocally committed parties. In fact, it is a commercial transaction, in which one party allows the other side to clone a proven business system in return for initial and ongoing costs. One of the participants is the franchisor, who identifies business opportunities and establishes a company that will exploit the identified opportunities. Another participant is franchisee, who purchases from the franchisor the right to apply a business model to a new geographic market. The franchisor usually provides a range of services such as training, supply of products and marketing plans and receives an initial fee and royalties in return (Gillis et al., 2014). Franchisor provides support to franchisees, but usually has some control over how they run their business. The success of the franchise system depends on the strength of the franchisor- franchisees relationship. Franchisor performs management functions such as strategic planning and marketing, while franchisee concentrates on customer service. Franchisees have significant idiosyncratic investments (e.g., lump-sum payment, the annual royalty fee based on sales), and franchisors provide support in management, operational procedures, training and promotion (Mignonac et al., 2013). Franchising business network produces something that neither of the two parties can produce on its own and something that can not be easily duplicated (Hakansson, Snehota, 1995). To achieve balance in their roles, franchisor and franchisee should work together as a team, with common goals that are placed above individual interests. Therefore, factors such as trust, cooperation, commitment and loyalty are crucial to the franchise relationship (Stefanović, Stanković, 2013).

Franchising can be seen as a commercial club, whose individual members collectively use "club products". These products are similar to public goods, because there is no rivalry in their use. However, they are not pure public good because it is not technically possible or overly expensive to exclude other potential users from consumption. In existing relationship between franchisors and franchisees, a trade mark can be seen as a public good. Collective consumption of goods can lead to well-known problem of "free rider". The costs of such a deviant behavior (for example- cheating) bears collectively group, but only individual who has such a behavior achieve benefits. Because of the possible occurrence of moral hazard, it is necessary for the franchisor to be able to monitor and enforce compliance of quality standards (Dnes, 1996). Franchise agreement does not constitute a fully integrated structure, but a hybrid form of vertical integration. A contractual relation between two or more companies is considered to be franchising, only if following conditions are met (Rudolph, 1999): 
1. There is one company, the franchisor, which continuously produces inputs over a long period of time (products, services and / or property rights) that are used only by a group of similar companies, franchisees.

2. In return, franchisees pay an initial franchise fee and royalty fees to the franchisor.

3. Franchise provides its franchisees a competitive advantage over other competitors who have not purchased the franchise.

4. Although the franchisee is not employed by the franchisor and has some freedom in its decision-making, the franchisor has the right to monitor franchisee's actions which can cause negative externalities for other franchisees.

5. Franchisor may, but does not have to be a company owned by entrepreneurs.

6. None of the franchisees does not have stake in the company owned by the franchisor.

Franchising is a powerful growth strategy which is proven as one of the most effective ways for brand to achieve global coverage. It is expected that franchising will provide better financial performances, supportive business environment and/ or a greater chance of survival than the alternative organizational forms (Nijmeijer et al., 2013). There is an increasing need for innovation in the franchise concepts in accordance with current trends in the global environment. On the one hand, it can be said that the most successful franchise systems are based on a proven business concept. On the other hand, proven franchise models could be declared as obsolete without the development of new products and innovative processes. Prior to the implementation of innovations in the franchise system, it is necessary to analyze advantages and disadvantages of implementing innovation. If it turns out that the expected positive effects are higher than costs, the implementation of innovations is justified. Otherwise, it is necessary to abandon the application of innovation. The term "innovative franchise" is not a technical oxymoron. However, the innovative franchise is not a common business model. From franchisees, it is expected to follow precisely defined procedures that determine what and how to produce and sell. However, even the most disciplined franchisors tend to apply new ideas (Stanković, 2013).

Agricultural franchising is one of innovations in the field of franchising and its implementation is still in the infancy. There are a few scientific papers on agricultural franchising as a new concept, and it is necessary to strive for the popularization of this business model. Prerequisites that must be met in order to apply the concept of agricultural franchising are as follows (Rudolph, 1999):

1. The limited growth potential of individual franchisees-In order to ensure simultaneous existence of a large number of franchisees, every individual franchisee should have limited growth potential in order. If there would be no restrictions on the growth of individual agricultural firms, then the most efficient company will grow without limits, slowly relegating its competitors.

2. A sufficient number of potential franchisees- In order to make a feasible franchise concept, franchisor must be able to sell franchise to a large number of franchisees. 
The more franchisees buy a franchise, the franchise will be more profitable for the franchisor. Franchisor will choose for their partner's franchisees who meet specific requirements. If the base of franchisees is bigger, franchisor can choose franchisee that is more appropriate for him as a business associate. Privatization has led to bigger base of potential franchisees in agriculture than in most other sectors.

3. Franchisor provide at least one of the managerial and administrative functionsKey managerial and administrative functions should be performed by a central organization, while secondary functions can be implemented by decentralized business units. Franchisor should have a specific production technology, because otherwise these functions could be provided by the unspecialized consultants and professionals. Providing these functions should contribute to improving the competitiveness of the franchisees. Important functions in the agricultural sector are transfer of managerial skills from the franchisor to the franchisees, improving access to capital markets by franchisees, centralized marketing and centralized procurement of inputs. Franchisees can use franchisor's information, technological and managerial advice and distribution channels. A necessary condition for the feasibility of franchising in the field of agriculture is that franchisor provides managerial and administrative functions in the form of exclusive rights to ensure its franchisees a competitive advantage over other firms.

4. Decentralized decision making-Franchising is more efficient concept in relation to fully integrated organization form because the costs of control of local managers are generally very high and their motivation and productivity depend on the entrepreneurial freedom. Taking into account negative experiences from the time of central planning in public agrarian companies that were part of a fully integrated vertical organization, it is evident that costs of controlling agricultural companies are very high. In this sense, the franchise concept has contributed to reducing the cost of supervision. This is consistent with the fact that franchisees tend to achieve goals of the franchise concept, because franchisee's success and profit depends on the franchise's profitability.

5. Franchisor's creditworthiness and long-term business strategy- To start a franchise business, significant investments are necessary. Franchisor need to bear high costs related to seeking out potential franchisees, providing training and coaching, as well as providing the right mix of managerial and administrative functions to offer to franchisees a competitive advantage. A key obstacle in starting a franchise concept in agricultural sector is high initial costs and lack of funding to cover these costs. If it is possible to provide the necessary investment, one of the prerequisites for initiating the concept of agricultural franchising will be filled.

6. Irrelevance of idiosyncratic investments- Idiosyncratic investments are contractually specific investments or investments that are related only to the specific contract and may not be important for potential agricultural franchisees. If idiosyncratic investments are relevant, a higher degree of vertical integration could be a more effective organization form for agricultural firms than franchising. Also, if transport costs are very high, agricultural firms will choose to integrate with the companies that are located in 
their immediate vicinity rather than to buy agricultural franchise. On the other hand, irrelevance of idiosyncratic investments will mean that franchise concept is more applicable in the comparison to other business models.

\section{Advantages and disadvantages of agricultural franchising}

Agricultural franchising has the potential to solve a number of problems associated with the agricultural sector in many countries. Therefore, it is crucial to develop a modified version of franchising that can serve as an alternative form of vertical organization for companies which produce agricultural products and provide agricultural services, especially in the transition economies. In developed market economies, many administrative and management functions are provided by agricultural extension services, cooperatives for marketing and purchasing and farmers' associations. In most developing countries these institutions either do not exist (for example, agricultural extension) or they have negative reputation (for example, cooperatives). Agricultural franchise agreement will be signed between agribusiness service company (the franchisor) and a number of farmers (franchisees). In return for a fee paid by the franchisees, franchisor will need to provide basic management and administrative functions. These functions are provided centrally by the franchisor and may include centralized marketing of outputs and procurement of inputs, management training and legal assistance. By providing such functions, franchisor can improve the competitive position of farmers who have become franchisees. Economic problems that occur in the agricultural sector, which can partially or fully be resolved by applying agricultural franchising are the following: outdated management techniques, lack of managerial talent, lack of access to credit markets, inadequate quality of available agricultural inputs and poor access to information on agricultural inputs and monopolistic market structures in the downstream sector. There are a number of advantages and disadvantages of franchising for both franchisors and franchisees. Advantages for franchisees which can be achieved by applying agricultural franchising are the following (Rudolph, 1999):

1. Multiplier effects of learning and transfer of management skills- From franchisees' perspective, the main advantage of franchising is the fact that they can use already tested business or product model and do not have to go through the painful process of "apprenticeship". In the past, directors of state companies and agricultural cooperatives performed orders routinely. Today, with the use of franchising, they became entrepreneurs who have a right to make their own optimal decisions in an uncertain market environment. They are now forced to apply management skills that have not had a chance to develop. Less innovative farmers can learn a lot from those more innovative through imitation. This imitative behavior leads to the process of technological diffusion. Strong geographical, political and language barriers can greatly affect the efficiency of the process of diffusion. If farmers continue to use outdated management techniques (especially in developing countries), their competitive advantage based on favorable climate, rich soil and abundantly available inputs will not be transformed into economic success. One of the central functions which 
agricultural franchisors have to provide to their franchisees is training for managing the franchise units. Transfer of human capital from franchisor to its franchisees requires a long-term perspective and usually offers a competitive advantage for franchisees. Agricultural franchisors from developed countries who transfer management skills to their franchisees from developing countries have a huge potential for success.

2. Access to credit markets- Agricultural franchising helps farmers to solve problem of financing investments through reducing transaction costs and improving execution of agricultural credits. If agricultural franchisor becomes an intermediary in providing loans to its franchisees, he will have to bear virtually no additional transaction costs, because he has already collected the relevant information while the selection of franchisees. Agricultural franchisor can manage franchisees' loans more efficient than agricultural bank, let alone a bank in another specific sector.

3. Centralization of marketing- Agricultural marketing cooperatives for coordinating sales activities of agricultural companies are often set up in the agricultural sector, so that they can gain an economic advantage in line with the increased negotiating power. Centralized marketing is a management function that offers significant advantages for agricultural franchising and therefore should be included in the mix of services that provides franchisor. Franchisor has a better negotiating position and can get more profitable contract with the buyer than a farmer.

4. Managerial and administrative assistance relating to the procurement of inputs- Potential benefits of centralized procurement of inputs represent another important advantage of agricultural franchising. Procurement of inputs is a management function provided by franchisor which allows franchisees to gain a competitive advantage.

From the perspective of a franchisee, potential disadvantage of agricultural franchising are initial and royalty payments which can be large, even more than in case of starting your own business. Franchisees have to pay percentage of the monthly gross to franchisor reducing their profit potential. Limited creativity and flexibility is very important disadvantage of agricultural franchising, because franchise contracts usually left little or no opportunities for franchisees to express their creativity. Most franchise contracts have very rigorous standards that cannot be changed without franchisor's permission which limits franchisees in their creativity. Also, one of potential disadvantages of agricultural franchising is its potential exploitative character. Before franchisees sign a franchise agreement, there is competition between different franchisor that offer franchise agreements and among various franchisees who are competing for the same territory of the same franchise. However, when franchisor and franchisee sign the contract, they enter into a bilateral long-term business relationship. Although franchise agreement may specify a number of unforeseen circumstances, it is beyond human capabilities to write a contract that covers all contingencies that may arise during the contract period. Franchisor may have more information about the relevant contingencies than franchisees, due to their previous experience. This leads to an asymmetric distribution of information about the relevant circumstances, so franchise agreements are considered as potentially exploitative for perspective franchisees (Rudolph, 1999). 
One of the most significant benefits for franchisors refers to the rapid expansion and faster coverage of agricultural markets through a large number of franchisees. In this way, larger franchise network can be formed and faster growth with less risk can be achieved. Also, franchisors can have a potentially high growth rate with less capital invested. Dynamic competition in market economies is one of drivers of economic growth. In the dynamic competitive process, firms that use their resources more effectively, achieve growth on account of other competing firms. Finally, the process of dynamic competition selects surviving companies and forces other companies into bankruptcy. Franchising enhances dynamic competitive forces through the improvement of franchisees' competitiveness which encourages economic growth. Agricultural franchising can perform pre-selection of franchisees based on their abilities and direct resources and investments to those franchisees that promise a higher probability of survival. Agricultural franchisor will have a strong economic incentive to take the pre-selection process similar to the one implemented the bank which assesses solvency of the loan applicant. This is because they will lose money if it turns out that their franchisee does not have skills necessary for success. The biggest disadvantages for franchisors are reduced ability to control franchisees, possible problems in relations with franchisees, as well as a lack of confidence in the franchise system (Centar za franšizing, Privredna komora Srbije, 2013).

Table 1. Pros and cons of franchising

\begin{tabular}{|c|c|}
\hline Pros & Cons \\
\hline \multicolumn{2}{|c|}{ FRANCHISEE } \\
\hline $\begin{array}{l}\text { Agricultural franchisor will provide the most } \\
\text { advanced management techniques, managerial } \\
\text { support and training to its franchisees for the } \\
\text { duration of the franchise agreement; } \\
\text { - Agricultural franchising will improve credit } \\
\text { usability and reduce transaction costs; } \\
\text { Agricultural franchisor will provide a sustainable } \\
\text { high quality of inputs and will improve information } \\
\text { for franchisees; } \\
\text { Agricultural franchisor will provide a competitive } \\
\text { advantage for franchisees through a centralized } \\
\text { marketing and procurement. }\end{array}$ & $\begin{array}{l}\text { - Agricultural franchisees have to pay initial and } \\
\text { royalty payments; } \\
\text { - Agricultural franchisees have limited creativity and } \\
\text { flexibility; } \\
\text { - Franchise contracthas potential exploitative character. }\end{array}$ \\
\hline \multicolumn{2}{|c|}{ FRANCHISOR } \\
\hline $\begin{array}{l}\text { Rapid expansion and faster coverage of } \\
\text { agricultural markets through a large number of } \\
\text { agricultural franchisees; } \\
\text { Agricultural franchisors have high growth rate } \\
\text { with less capital invested; } \\
\text { Agricultural franchisor will choose the most } \\
\text { talented entrepreneurs and sign the franchise } \\
\text { agreement only with those franchisees that } \\
\text { passed the process of screening and selection. }\end{array}$ & $\begin{array}{l}\text { - Agricultural franchisor has reduced ability to } \\
\text { control franchisees; } \\
\text { - Agricultural franchisors can have possible } \\
\text { problems in relations with franchisees; } \\
\text { - Lack of confidence in the franchise system. }\end{array}$ \\
\hline
\end{tabular}

Source: Rudolph, 1999. 


\section{Agricultural franchising - a hybrid form of disinvestment in conditions of economic crisis}

Franchising is almost unstoppable engine of growth in the global economy. However, in the light of the recent global recession, pressure is exerted on many business formats, especially with regards to downsizing. However, given the unique context of the franchising business model, this measure has a different meaning in this case. The relationship between the franchisor and franchisees is not the same as the relationship between employer and employee and thus traditional forms of dismissal considered invalid. Moreover, many franchise agreements are concluded for a period of 10 or even 20 years, so that short-term measures of temporary staff reductions are not feasible. The period of recession can even be useful for the franchise network that was flared excessively in the past. Challenging time for the economy forced some franchisees that simply are not able to survive to close their franchise units. Therefore, the economic decline can have unintended beneficial effect of "cleaning" in franchising, despite another very harmful consequences. The definition of business failure takes on a completely unique significance in the context of franchising. It is because a failure of franchised units can be hidden behind reacquisition strategy (reacquisition of non-functional unit by the franchisor and its subsequent sale to a third party), (Dant et al., 2011).

The need to cope with limited resources and constantly changing business environment compels firms on restructuring. Disinvestment strategy can be seen as an opportunity to change the destination of the investment and to adapt to the new competitive situation. Disinvestment transactions are transactions which cause intermittent and significant reductions of engaged resources and the elimination or extraction of business segments. These transactions often result in the formation of new business entities resulting from the company that disinvests. Disinvestment is traditionally associated with the conditions of economic crisis, when it can be considered as one of the options for the company's growth. It is pointed out that the main reasons for disinvestment (sale of business units) are actually poor performances and unfavorable expectations about future of some business units. Disinvestment should not be seen as the opposite of investment, but as a solution to financial problems and poor business results. In fact, disinvestment is one of the possible strategic alternatives that enable business growth through different resource deployment. Disinvestment mainly involves complete loss of control of the sold business, but it is not a rule. Strategic objectives of disinvestment can be realized through transactions that do not always involve sale of the entire company. These are "hybrid" disinvestment that attracts attention for several reasons. From a management perspective, they are important because they represent an alternative way of enhancing company's opportunities and providing a strategic renewal without the need for long-term investments.

Franchising as a hybrid form of disinvestment includes the creation of a new relationship between the franchisor and franchisees. In a franchise system, business network's corporate culture is strongly influenced by the process of selection and evaluation of franchisees. Disinvestment through franchising should be seen as a means of business development, especially in conditions of economic crisis. Special environmental conditions and strategic goals can motivate the company to use an agricultural franchising as a form of disinvestment. 
Disinvestment through the agricultural franchising differs from other disinvestment forms because there is strict and formal control over the franchisee's activities. Also, there is very little risk to increase competition within the franchise system, because the relationship between franchisor and franchisees is mainly long-term and based on mutual trust. The main advantage of the agricultural franchising as a form of disinvestment lies in the nature of franchising compared to hierarchical organizations: strict control of independent individual enterprises through a "soft" hierarchy. Agricultural franchising is considered to be a quick way to achieve growth with limited capital investment.

In the conditions of economic crisis, agricultural enterprises often decide to franchise their business. The most common reasons for this are the lack of financial resources for conducting business, learning through business network expansion and internationalization of business. The franchise agreement is often mentioned as an ideal business format business in an unstable environment. However, the selection of franchisees and franchise locations are issues which should be taken into account, especially in conditions of economic crisis. A key motives for disinvestment through agricultural franchising are the following: faster growth at the global level and business network expansion, financial motives and the need for efficiency, internationalization of business (opening franchise locations in countries that are less affected by the negative effects of the economic crisis) and reduce of logistics costs. The main results of the application of agricultural franchising as a disinvestment model are: improvement of the average return per unit, higher total return and increased sales per unit (Baroncelli, Manaresi, 1997).

\section{Agricultural franchising and objectives of the Common Agricultural Policy of the EU}

The Common Agricultural Policy is the first EU policy that was usually focused on ensuring a fair standard of living for farmers over the 50 years long history (Riley, 2010). From its inception until today, CAP has experienced a large number of changes (Živadinović, Milovanović, 2011). In fact, measures that are oriented toward the realization of the set goals were changed over time. The EU Member States were able to grow from a net importer to a net exporter of agricultural products through the effective implementation of the Common Agricultural Policy. The main challenge, in the agricultural sector of the EU, will be to preserve the supranational character of the Common Agricultural Policy, due to the increasingly intensive efforts of member states, to create their own goals of rural policy and make a decisive impact on CAP (Živadinović, 2008). The Common Agricultural Policy is one of the most important drivers of European integration and survival of the EU. The key contribution of CAP is that it brought safe, stable and continuous supply of agricultural products to EU citizens (Martini, 2011).

The Common Agricultural Policy is a significant budgetary policy of the EU, which is fully established at the EU level and mainly financed from the EU budget (Erjavec et al., 2011). Because of high spending for CAP from the budget, it is often a stumbling block in making European budget. The Common Agricultural Policy is actually the first EU policy which provided the highest level of integration. From the very beginnings of CAP, it was clear that the integration of agricultural markets can not be performed as a negative integration (the 
elimination of tariffs and other trade barriers), but rather as positive integration (replacement of national institutions and supranational organizations) (Brummer, Koester, 2003). Today's CAP is a result of changes and reforms that have been implemented over more than a half of the last century) last more than half a century. The focus of the CAP is to promote the multifunctional model of agriculture (Cardwell, 2006). CAP is a metaphorical living organism that responds to external and internal changes and enters them into its composition. Internal changes are related to changes in the internal market of agricultural products, while external changes include changes in the international market of agricultural and products (Milosavljević et al., 2008). Global trends point out more intensive liberalization of the agricultural sector, increasing level of agricultural production, specialization of production and integration into multinational companies (Vujičić, Đekić, 2003).

The key advantages of the CAP are: ensuring sufficient food for the population at any given time, EU was turned from a net importer into a net exporter of food, improving living standards of the rural population, increasing productivity of agricultural production, improving environmental protection and development of underdeveloped rural areas. There are certain disadvantages of CAP related to: excessive market surpluses that burden the budget, negative impact on soil, water, air, food safety and quality, un-fulfilment of one of the main goals of CAP - the development of rural areas, negative impact on the global flows in agricultural products trade. The main principles underlying the CAP are: single market, priority and financial solidarity (OECD, 2011). The single market is a principle which involves free movement of goods between member countries without customs and other charges with unique tariff rates for imported products. Therefore, the first principle relates to free trade within the community based on common prices. Priority is reflected in the precedence of EU products over imported products. Domestic market can be protected from foreign competitors through the special instruments (special import duties). On the other hand, there is help in placement of goods produced in EU to foreign markets through export subsidies. Financial solidarity involves joint financing of CAP's measures and mechanisms by member countries. So, all EU member states participate in costs of CAP, although the share in financing costs is not the same for all member states. CAP is determined by government of member states at EU level and it is implemented by the member states (Lovec, Erjavec, 2012). Today, CAP aims to encourage raise of product quality and to enable farmers to produce sufficient amounts of safe, high quality food for European consumers with respect to very high standards of environmental protection. The main objectives of the CAP are the following (Živadinović, Milovanović, 2011):

- Increasing the productivity of agricultural sector (primarily by improvement of technical development, rationalization of agricultural production and the optimal use of production factors);

- Ensuring a fair living standard for farmers (particularly by increasing wages in agriculture);

- Market stabilisation;

- Regularity in food supply; 
- Ensuring acceptable price for consumers (ensuring reasonable prices of agricultural products).

The implementation of agricultural franchising can contribute significantly to the achievement of these goals. Primarily, the franchise concept ensures rationalization of agricultural production, as franchisees operate under the well-known business name and with constant monitoring from the franchisor. Technical development and rapid diffusion of technology among franchisees contribute to increase productivity of the agrarian sector. Agricultural franchising ensures an optimal use of production factors. In fact, franchisors usually supply franchisees with production factors and provide support in management of inputs. Considering that franchisors have previous greater experience in the management of inputs, it is possible to provide more optimal and rational use of available factors of production. Another stated goal of the CAP is to ensure a fair living standard for farmers. Agricultural franchisees use proven business model that survives on the market for a long period of time, so they face less risk than in the case of starting their own business. Thus, they have much lower initial startup costs and they can achieve better earnings with less investment. Agricultural franchisees are committed to a profitable business of franchise unit and thus have an influence on their potential earnings.

Through dispersion of famous agricultural companies by franchise units all over the world, agricultural products will be available to a large number of people at affordable prices even in the developing countries. Agricultural companies from developing countries accept franchise concept within which they can rely on franchisor from some developed country in terms of management, training and support. In this way, the development of the agrarian sector is encouraged by expanding the network of franchise units and market of agricultural products is stabilized. In accordance to more intensive dispersion and increased number of franchisees it will be ensured regularity in food supply, even in the regions where there was a problem of insufficient agricultural products. For consumers, it will mean more security in terms of agri-food products they buy. In this way, trust and commitment to the products of a given brand will be built, by offering standard products and quality through proven business system. Another objective of the CAP is to guarantee acceptable prices of agrifood products to consumers. Franchisor mainly determines the recommended product price, which franchisees need to comply. If franchisee put a lower product price, he could become a competitor to other franchisees and the franchisor. On the other hand, self-determination of higher prices by franchisees would also lead to inconsistencies in the entire franchise system. Therefore, compliance with price recommended by the franchisor ensures reasonable prices for consumers.

\section{Conclusion}

The Common Agricultural Policy has provided the highest level of integration in the agricultural sector of the European Union. Today's CAP is a result of reforms that have been implemented over the last more than 50 years. Each of the reforms demanded the implementation of a number of innovations, all in order to achieve defined priorities of agricultural policy. Agricultural franchising is certainly one of the innovative concepts 
which require an intensive use in the agricultural sector. Through the growing number of franchise units, agricultural franchising can provide better financial results than alternative organizational forms, since it is a proven business model in which the risk is much lower than that of starting a business.

In order to implement the agricultural franchising concept, it is necessary to fulfill certain conditions related to: limited growth potential of individual franchisees, sufficient number of potential franchisees, providing at least one of the managerial and administrative functions by the franchisor, decentralized decision making, franchisor's creditworthiness and long-term business strategy and irrelevance of idiosyncratic investments. Agricultural franchising has the potential to solve economic problems that occur in the agricultural sector. Problems are: outdated management techniques, lack of managerial talent, lack of access to credit markets, inadequate quality of available agricultural inputs, insufficient access to information on agricultural inputs and monopolistic market structures in downstream sector. Agricultural franchising provides a number of advantages for the agricultural sector of the EU member states and solves mentioned problems completely or partially. In conditions of economic crisis, companies are motivated to use an agricultural franchising as a form of disinvestment in order to achieve faster growth at the global level, business network expansion, financial benefits, internationalization of business and reduce of logistics costs.

Agricultural franchising contributes to achieving the objectives of the Common Agricultural Policy of the European Union. The main goals of the CAP are: increase in productivity of the agrarian sector, ensuring a fair living standard for farmers, market stabilization, regularity in food supply and guaranteeing acceptable prices to consumers. First of all, agricultural franchising ensures faster technology dispersion among franchisees, resulting in greater rationalization and productivity of the agrarian sector, through optimal use of production factors. Initial costs, for starting agrarian franchise units, are smaller than for the establishment of new agribusiness, franchisees can achieve greater profits with less investment and thus ensure a fair living standard for themselves. Availability of agricultural products and stabilization of the agricultural market will be provided through the dispersion of famous agricultural companies, by franchise units on global level. Increasing the number of agricultural franchisees will enable the regularity in the supply of agricultural products, especially in regions where there was a problem of insufficient food. Considering that franchisor generally determines the recommended product price which franchisees comply, reasonable prices of agricultural products are ensured for consumers.

\section{Literature}

1. Baroncelli, A., Manaresi, A. (1997): Franchising as a Form of Divestment: An Italian Study, Industrial Marketing Management, vol. 26, pp. 223-235.

2. Barthelemy, J. (2008): Opportunism, knowledge, and the performance of franchise chains, Strategic Management Journal, vol. 29, pp. 1451-1463.

3. Brummer, B., Koester, U. (2003): EU enlargement and governance of the common agricultural policy, Intereconomics, vol. 38, no. 2, pp. 86-93.

EP 2014 (61) 4 (1021-1035) 
4. Cardwell, M. (2006): Agricultural policy in Europe, Common Market Law Review, vol. 43, no. 3, pp. 909-911.

5. Centar za franšizing, Privredna komora Srbije, Franšizing - najčešće postavljana pitanja, available at: www.pks.rs/SADRZAJ/Files/Frans\%20brosura.pdf, accessed at: 28.08.2014.

6. Dant, R., Grünhagen, M., Windsperger, M. (2011): Franchising Research Frontiers for the Twenty-First Century, Journal of Retailing, vol. 87, no. 3, pp. 253-268.

7. Dnes, A. W. (1996): The economic analysis of franchise contracts, Journal of Institutional and Theoretical Economics, vol. 152, pp. 297-324.

8. Erjavec, E., Chantreul, F., Hanrahan, K., Donnellan, T., Salputra, G., Kožar, M., Van Leeuwen, M. (2011): Policy assessment of an EU wide flat area CAP payments system, Economic Modelling, vol. 28, no. 4, pp. 1550-1558.

9. Gillis, W. E., Combs, J. G., Ketchen, D. J. (2014): Using Resource-Based Theory to Help Explain Plural Form Franchising, Entrepreneurship Theory and Practice, vol. 38, pp. 449-472.

10.Hakansson, H., Snehota, I. (1995): Developing Relationships in Business Networks, Routledge, London.

11. Lovec, M., Erjavec, E. (2012): , Big bang” enlargement and common agricultural policy reform, Društvena Istraživanja, vol. 21, no. 1, pp. 219-238.

12. Martini, R. (2011): Long Term Trends in Agricultural Policy Impacts, OECD Food, Agriculture and Fisheries Working Papers, vol. 45, OECD Publishing.

13.Mignonac, K., Vandenberghe, C., Perrigot, R., El Akremi, A., Herrbach, O. (2013): A Multi-Study Investigation of Outcomes of Franchisees' Affective Commitment to Their Franchise Organization, Entrepreneurship Theory and Practice, available at: http:// onlinelibrary.wiley.com/doi/10.1111/etap.12050/pdf

14. Milosavljević, S., Milošević, M., Milovanović, M. (2008): Poljoprivreda Srbije i međunarodne integracije, Agroprivreda Srbije i evropske integracije - gde smo i kako dalje, DAES - Društvo agrarnih ekonomista Srbije, Novi Sad, pp. 13-19.

15.Nijmeijer, K., Fabbricotti, I. N., Huijsman, R. (2013): Making Franchising Work: A Framework Based on a Systematic Review, International Journal of Management Reviews, vol. 16, no. 1, pp. 1-22.

16. OECD (2011): Evaluation of Agricultural Policy Reforms in the European Union, OECD Publishing.

17. Riley, J. (2010): CAP Reform The industry reacts, Farmers Weekly, vol. 153, no. 21, pp. 22-23.

18. Rudolph, D. (1999): Vertical Organization of Agribusinesses in Transition Economies: Hungarian Production Systems or Agricultural Franchising?, Agribusiness, vol. 15, no. 1, pp. 25-40. 
19. Stanković, M. (2013): Značaj inovacija za razvoj franšiznih sistema, Škola biznisa, vol. 3-4, pp. 193-211.

20. Stefanović, S., Stanković, M. (2013): Komparativna analiza razvoja franšizinga u Srbiji i svetu, Marketing, vol. 44, no. 2, pp. 115-128.

21. Vujičić, M., Đekić, S. (2003): Agrobiznis: sistem, upravljanje i razvoj, Ekonomski fakultet u Kragujevcu, Kragujevac

22.Živadinović, B., Milovanović, M. (2011): Vodiči kroz EU politike - Poljoprivreda, Evropski pokret u Srbiji, Beograd.

23.Živadinović, B. (2008): ZAP EU: Iskustva novih država članica i perspektive agroprivrede Srbije, Tematski zbornik Evropska unija i Zapadni Balkan - Izazovi za agroprivredu Srbije: Šta nam je činiti?, DAES, Beograd, pp. 35-49.

\title{
AGRARNI FRANŠIZING I DOPRINOS OSTVARENJU CILJEVA ZAJEDNIČKE AGRARNE POLITIKE EU
}

\author{
Milica Stankovic ${ }^{3}$
}

\section{Rezime}

Zajednička agrarna politika je najstarija, najkompleksnija i najskuplja politika EU $i$ predstavlja jedan od najvažnijih pokretača evropskih integracija. Agrarni franšizing je jedna od inovacija u oblasti franšizinga čija je implementacija još uvek u povoju, te je neophodno zalagati se za popularizaciju ovog poslovnog modela. Cilj rada je da se ukaže na značaj razvoja koncepta agrarnog franšizinga i doprinos implementacije ovog koncepta ostvarenju ciljeva Zajedničke agrarne politike Evropske unije i unapređenju agrarnog sektora u celini. Posebna pažnja je posvećena agrarnom franšizingu kao hibridnom obliku dezinvestiranja u uslovima ekonomske krize. Na osnovu analize prednosti i nedostataka agrarnog franšizinga zaključuje se da agrarni franšizing ima potencijal za rešavanje velikog broja problema koji se javljaju u agrarnom sektoru, sa posebnim naglaskom na značaj agrarnog franšizinga za ostvarenje ciljeva ZAP.

Ključne reči: Zajednička agrarna politika, EU, agrarni franšizing, dezinvestiranje, ciljevi ZAP.

3 Milica Stanković, M.Sc., Saradnik u nastavi, Visoka poslovna škola strukovnih studija u Novom Sadu, Vladimira Perića Valtera 4, 21000, Novi Sad, Telefon: +381 2148540 00, E-mail: milica. stankovic.vps@gmail.com

EP 2014 (61) 4 (1021-1035) 